\title{
АНТРОПОЛОГІЧНІ ТА ІДЕОЛОГІЧНІ НАСЛІДКИ МЕДІАТИЗАЦІї
}

\author{
Тарас Лильо \\ Львівський національний університет імені Івана Франка \\ вул. Генерала Чупринки, 49, 79044, Львів, Україна \\ e-mail: taras.lylo@lnu.edu.ua \\ https://orcid.org/0000-0003-1673-6648
}

У статті проаналізовано явище медіатизації, під час якого суспільні та культурні реалії, цінності набувають медійних форм. Розглянуто, зокрема, такі антропологічні та ідеологічні наслідки медіатизації, як homo videns, світ постідеї, мережева егалітаризація.

Ключові слова: медіатизація; 3MI; homo videns; телебачення; ідеологія; інтернет.

\section{1. Постановка проблеми}

Медіатизація (нім. Mediatisierung - «опосередковано залежний», від лат. medius - осередок, середній, опосередкований) в історичному контексті означає елемент посередництва чи навіть залежності від когось або чогось. У більшості досліджень журналістикознавців та соціологів ЗМІ цей елемент є ключовим у трактуваннях медіатизації. У такому розумінні медіатизації об'єктом впливу є не лише суспільні реалії, а й посередник цього впливу - медіа. Насамперед йдеться про використання ЗМІ владою, олігархами тощо. Однак сучасне значення ЗМІ, їхній статус, особливо у транснаціональному вимірі, дає підстави стверджувати, що медіа спроможні бути суб'єктом ідеологічного, культурного узалежнення, тобто точкою відліку у формуванні системи цінностей, динаміки антропологічного процесу. Саме такі тенденції вказують на актуальність теми. Мета дослідження - виявити антропогенетичні та ідеологічні можливості 3МІ у контексті проблеми медіатизації. Поставленні у статті завдання полягають у систематизації сучасних досліджень про медіатизацію, з'ясуванні основних історичних етапів утвердження медіатизаційних можливостей 3MI, визначенні специфіки формування homo videns, світу постідеї та ідеології інтернету, зокрема, як вона впливатиме на майбутнє журналістики.

\section{2. Теоретичне підгрунтя}

Дефініції. Медіатизацію трактують як «процес опосередкування через медіа усіх сфер суспільного життя, під час якого ключові елементи суспільної та культурної активності набувають медійних форм» ${ }^{1}$. Інакше кажучи, цей термін вказує на велике значення ЗМІ в розумінні, пізнанні, творенні суспільних порядків. Згідно з Ва-

\footnotetext{
1 Livingstone, S. (2009), «On the mediation of everything: ICA presidential address 2008», Journal of communication, vol. 59 (1), p. 6.

(C) Лильо Т., 2020
} 
лерієм Пісареком, медіатизація (mediatisation, фp. médiatisation, нім. Mediatisierung) «означає процес опосередкування ЗМІ у пізнанні світу; влив медіа на сприйняття безпосередньо недоступної реальності з усіма наслідками такого опосередкування: формуванням образу усіх суспільних реалій та цілісного суспільного досвіду»².

Польська дослідниця Малгожата Моленда-Здзєх³ вважає, що у контексті медіатеорій медіатизація належить теоретичним напрямам, які описують односторонню залежність людини від ЗМІ. По-перше, йдеться про теорію культивації Джорджа Гербнера ${ }^{4}$ та Ларрі Гросса, яка, зокрема, вказує на залежність між телемовленням і переконаннями й поведінкою авдиторії та стверджує, що «надмірний перегляд телебачення «культивує» таке сприйняття реальності, яке узгоджується з реальністю, продемонстрованою у телепрограмах».

По-друге, наголошують на теорї сnіралі мовчання: людина, погляди якої виражають думку меншості, не бажаючи бути ізольованою у своєму оточенні, вибирає мовчання. У цьому процесі 3МІ беруть безпосередню участь. Саме вони, згідно 3 твердженням авторки цієї теорії Елізабет Ноель-Нойманн, «не тільки говорять нам, про що думати, але й надають єдиний санкціонований погляд на те, як решта про це думає» ${ }^{5}$.

По-третє, згадують гіпотезу про порядок денний, згідно з якою медіа створюють своєрідні ієрархії тем. «Усі дані вказують на те, що люди задумуються над почутим, але в жодному разі не над тим, чому чують саме це, а не щось інше» ${ }^{6}$. Умберто Еко говорить про тематизацію у пресі як спосіб імпліцитної оцінки навіть тоді, коли ЗМІ чітко розділяє факт і коментар. Він каже, що останнім часом поширився принцип добору тем, згідно з яким на одній сторінці розміщують тематично споріднені інформації, і наводить приклад 3 газети «La Repubblica» (22 січня 1997 р.). На сімнадцятій сторінці цієї щоденної газети опубліковано чотири матеріали з такими заголовками: «Брешія, народжує й умертвляє дочку»; «Рим, чотирирічна дитина, самісінька вдома, бавиться на підвіконнику»; «Рим, в лікарні може народити навіть жінка, яка не хоче дитини»; «Тревізо, після розлучення мама зрікається своїх материнських обов'язків». На думку італійського дослідника, маємо справу з тематизацією важливої проблеми покинутих дітей, незалежно від того, чи є це дуже актуальна проблема для певного періоду, чи ні. Така техніка може бути коректною, але водночас показує, як, оперуючи тенденційно дібраними фактами, можна маніпулювати читачем.

Інші дослідники вказують на те, що медіатизація є «тривалим і компактним процесом, в якому найбільшу роль відіграють регулярні журналістські практики у сфері селекції інформації (gatekeeping) та загальноприйнятого конструювання світу»7. Тобто викривлення подій спричинене не лише фальшуванням фактів, а й се-

\footnotetext{
2 Pisarek, W. (2006). Stownik terminologii medialnej, Universitas, Kraków, s. 118.

3 Molęda-Zdziech, M. (2013). Czas celebrytów. Mediatyzacja życia publicznego, Difin SA, Warszawa, $444 \mathrm{~s}$.

${ }^{4}$ Gerbner, G., Gross, L., Morgan, M., \& Signorielli, N. (1986). Living with television: The dynamics of the cultivation process. In J. Bryant \& D. Zillman (Eds.), Perspectives on media effects, Lawrence Erlbaum Associates, NY, pp. 17-40.

5 Powerful effects-minimal effects: Elisabeth Noelle-Neumann, «The Effect of Media on Media Effects Research,» Journal of Communication, Vol. 33, No.3, 1983, pp. 157-165.

6 Trenaman J., McQuail D. (2007). Television and the political image, Menthuen, London, p.178.

7 Pisarek, W. (2006). Stownik terminologii medialnej, Universitas, Kraków, s. 118.
} 
лекцією та оцінкою подій, насамперед з погляду головних медійних гравців. Така медіатизація відбувається в різних формах. Сжи Олендський ${ }^{8}$ серед інших визначає такі: 1) перебільшення значення неістотних подій; 2) абсолютизація фрагменту, представлення його як такого, що передає повноту подієвої картини: інформацію виривають із політичного, суспільного... контексту, тобто з контексту реальності; 3) погляд на подію з точки зору вигоди, інтересів певного інформаційного агентства; 4) замовчування невигідних для країни походження інформаційного агентства чи медіакорпорації подій...

Термін медіатизація з'явився у політичному контексті. Сьогодні, крім медіатизації політики ${ }^{9}$, дослідники говорять про медіатизацію суспільства, медіатизацію культури $^{10}$, медіатизацію мови ${ }^{11}$, медіатизацію релігії ${ }^{12}$, медіатизацію споживатства ${ }^{13}$ тощо.

\section{4. Методологічна основа дослідження}

3 емпіричних методів у статті використано порівняння, зокрема під час вивчення відмінностей між homo sapiens та homo videns, а також спостереження, що дало змогу констатувати перетворення ЗМІ у самодостатній суб’єкт впливу на реальність. Для дослідження історії медіатизації застосовано історичний підхід.

\section{5. Виклад основного матеріалу дослідження}

Історія медіатизації. Термін медіатизація вперше використав шведський соціолог Кент Асп у 1986 році, однак саме явище з'явилося ще задовго до його номінації. Свою історію преса починає у XVII столітті. Вже одна з перших газет того часу, що була створена за ініціативою кардинала Рішельє, «La Gazette» Теофраста Ренодо, чітко визначає свою політичну мету: захист молодої монархії від консервативного феодально-демократичного дворянства, релігійної нетолерантності, сепаратистських тенденцій; захист політичних та культурних реформ у державі, а також зміцнення міжнародного авторитету Франції. Завдання газети Ренодо окреслює дуже чітко: писати історію сучасності навіть того ж дня, коли її читатимуть. Вмираючи, редактор метафорично порівняв пресу з бурхливими течіями, потужність яких вона збільшує своїм опором. Така здатність преси виявилася уже в наступному столітті, особливо під час Американської (1775-1783) та Великої французької революцій (1789-1799), історія яких писалася на сторінках газет, що часто ставали суб’єктами революційної дії з чітко окресленою риторичною стратегією на зразок газети Марата «L’Ami du peuple». Попри свій «золотий вік» преса у XIX столітті є знаряддям політичного впливу, насамперед Наполеона («Courrier de l'Armée d'Italie», «La France vue de l'Armée d'Italie», «Le Moniteur Universel»), Бісмарка („Neue Preussiche Zeitung), Лінкольна («Chicago Tribune»). Саме у XIX столітті газета Камілло Бенсо ді Кавура «Risórgimento» дає назву рухові за об’єднання Італії. Тоді ж американсько-іспанську

8 Olędzki J. (1998). Komunikowanie w świecie, ASPRA, Warszawa, s. 44.

9 Mazzoleni, G. (2008), «Mediatization of politics». In: Donsbash W (ed) The international encyclopedia of communication, vol VII, Blackwell, Malden, pp 3047-3051.

${ }^{10}$ Hjarvard, S. (2008), «The mediatization of society. A theory of the media agents of social and cultural change», Nordicom Review, no. 29(2), pp. 105-134.

${ }^{11}$ Ibid.

${ }^{12}$ Ibid.

13 Jansson, A. (2002), «The Mediatization of Consumption: Towards an Analytical Framework of Image Culture», Journal of Consumer Culture, vol. 2, no. 1, pp. 5-31. 
війну 1898 року було названо «Війною Газети» $з$ огляду на великий влив у розпалюванні згаданої війни газети Вільяма Рендольфа Герста «New York Journal».

У першій половині XX століття поряд із пресою («Искра», «Правда», «Völkischer Beobachter», «Der Angriff») серед засобів медіатизації утверджується кінематограф (Сергій Ейзенштейн, Лені Ріфеншталь) та радіо, яке відіграло одну з головних ролей у поширені більшовицької та, особливо, нацистської пропаганди. Прикметно, що радіо мало значний вплив як на створення СРСР, так і на його розпад. Радянський Союз як гігантська псевдоінформаційна структура, в якій до критичного рівня нагромадилася брехня, не витримав конкуренції з такими представниками міжнародного радіомовлення, як «Радіо Свобода», «Голос Америки», «Бі-Бі-Сі»... Під кінець століття (1994) державне «Радіо Руанда» спровокувало масові вбивства тутсі в провінції Бугесера. Це один з найкривавіших наслідків медіатизації за останні десятиліття.

Попри величезні можливості радіо медіатизувати дійсність, у минулому столітті саме телебачення спричинилося до якісно нових маніпулятивних наслідків цього процесу: воно стає антропологічним засобом, тобто може створювати новий тип людини.

Homo videns. Концепція «homo videns» Джованні Сарторі $є$ противагою «негропонтизму» Ніколаса Негропонте, який трактує ЗМІ лише як інструмент розвитку демократичної цивілізації. На думку італійського медіазнавця, переймаючись тим, що телебачення поширює образи насилля, погано інформує глядачів, є культурно регресивним ЗМІ (як пише Ю. Габермас), ми втрачаємо з поля зору той факт, що воно змінює людську природу: перетворює homo sapiens y homo videns. Така трансформація прямо пов'язана з витісненням словесної культури культурою образу. Хоча першим справжнім засобом масової інформації було радіо, воно «не порушувало символічної природи людини» ${ }^{14}$, адже поширювало виражений у словах зміст. 3 розвитком телебачення у другій половині XX століття настає фундаментальна зміна: відеообраз починає домінувати над образом словесним. Згідно з Дж. Сарторі, це змінює напрям розвитку, тобто наскільки здатність на символічне мислення відрізняє homo sapiens від тварин, настільки схильність до перегляду наближає його до первісної природи. Дослідник ставить знак рівності між homo videns i homo insipiens - людина нерозумна, яка втрачає здатність до абстрактного мислення, до раціональності й не спроможна підтримати створений homo sapiens світ. «Тут ми маємо справу 3 простою бездумністю, банальним впаданням у безглуздість і неможливістю сформулювати чіткі та зрозумілі ідеї. Вина телебачення полягає в тому, що воно надає перевагу мисленнєвому хаосу. Телебачення винагороджує марнотратність, нісенітниці й сенсацію. Таким чином, це зміцнює позицію homo insipiens» $»^{15}$.

Одним із виявів телемедіатизації є недоінформування глядача, адже на телебаченні істотно змінюються критерії добору та ієрархізації інформації: значення має інформація з найкращою картинкою. Якщо забракне відео, інформація не вийде в ефір, ïï потрактують як таку, що не варто подавати. Інакше кажучи, маємо справу 3 псевдоінфляцією подій. Як наслідок, пріоритетними для телеефіру стають найдоступніші для телеоб’єктива локальні події, а міжнародні новини згортають. Оскіль-

\footnotetext{
${ }^{14}$ Sartori, G. (2007). Homo videns. Telewizja I postmyślenie, wyd. Uniwersytetu Warszawskiego, Warszawa, s. 17.

${ }^{15}$ Sartori, G. Op. cit., s.86.
} 
ки homo videns сприймає світ за принципом «те, що невидиме, цього не існує (Non vidi, ergo non est)», людина втрачає цілісну візію світу, який щоразу менше її цікавить. Джованні Сарторі називає це гігантською ампутацією розуму й різко критикує принцип «попит породжує пропозицію», стверджуючи, що громадськість, яку не цікавило падіння Берлінської стіни, - це вихована великими американськими телемережами спільнота. Якщо їі увага зосереджена на локальних новинах і на кримінальній хроніці, то тільки тому, що телебачення виховало громадян, які мало що знають і мало чим цікавляться.

Із необхідністю «показувати» Дж. Сарторі пов’язує появу на телебаченні псевдоподій, які відбуваються тільки тому, що їх знімає камера. Така тенденція спричиняється, зокрема, до маніпулятивної підміни виборів на відеовибори, внаслідок чого відбувається персоналізація політики та їі емоціоналізація - обмеження політики до емоцій, коли «на глядачів йде лавина зворушливих історій, що роздирають душу й серце, маргіналізуючи в такий спосіб ті актуальні проблеми, які вимагають дискусії» ${ }^{16}$. Таким чином, культура образу руйнує рівновагу між емоціями й раціональністю (ця рівновага притаманна писемній культурі). Емотивна відеополітика порушує проблеми, але не подає жодної ідеї, як їх розв'язати, і в такий спосіб їх ускладнює.

Не впадаючи у відчай, Джовані Сарторі не приховує, що домінування простацтва в людському мисленні (постмислення) ще попереду. На його думку, цьому зможемо запобігти, коли навчимося за будь-яку ціну захищати книжки, навички читання та писемну культуру.

Світ постідеї. Песимістичні прогнози Дж. Сарторі актуалізує автор наукового есею «Недосяжна велика ідея» (The Elusive Big Idea) Ніл Габлер, але вже у контексті комунікування в соціальних мережах. Аналізуючи представлені в журналі «Atlantic Monthly» «14 найбільших ідей року», американський дослідник констатує їхню несправжність, тобто спробу подати банальні спостереження, як ідеї. На його думку, «ідеї не є вже тим, чим були. Колись вони спричиняли запеклі дебати, надихали, започатковували революції і фундаментально змінювали наш спосіб розуміння i сприйняття світу. Вони потрапляли теж до масової культури й робили мислителів знаменитими - як-от Альберт Ейнштейн чи Даніель Белл. Навіть самі ідеї набували розголосу: наприклад, «смерть ідеології», «містика жіночості», «теорія великого вибуху». Великі ідеї могли з'явитися на обкладинці тижневика «Тайм»...»". Однією з причин появи світу постідеї Ніл Габлер вважає комерціалізацію, в системі пріоритетів якої поява великих ідей є проблематичною, бо вони не відразу окуповуються та мають малу внутрішню вартість. Ознаки такого стану речей фіксують традиційні 3MI, в яких дослідник бачить згортання інтелектуальних публічних дебатів у основних ЗМІ, а також брак мислителів, які би самовпевнено викладали думки. Цьому сприяв занепад есеїстики в суспільно-культурній пресі. Натомість поширюється візуальна культура, особливо серед молоді, тобто форма, в якій ідеям щоразу важче виявлятися. Однак справжнім винуватцем того, що ідеї - це passé, Н. Габлер вважає інформацію, яка ускладнює появу ідей згідно з правом Грешама. Сучасна людина надає перевагу поінформованості перед думкою, йдеться про інформацію переважно особистого характеру. «Куди ідеш? Що робиш? 3 ким бачишся? - це великі питання

\footnotetext{
${ }^{16}$ Sartori, G. Op. cit., s.59.

${ }^{17}$ Gabler, N. (2011), «The Elusive Big Idea», The New York Times, Aug. 14.
} 
Лильо T.

нашого часу», - констатує автор згаданого есе й наголошує на невипадковості народження світу постідеї водночас зі світом соціальних мереж. На його думку, вони, по-перше, є основною формою комунікації для молоді й починають замінювати друк, а саме за допомогою друку, насамперед, виражали ідеї. По-друге, соціальні мережі впроваджують навики думки, які не сприяють дискурсові, що започатковує ідеї: замість теорій, гіпотез та істотних аргументів отримуємо закладений у 140 знаків запис про поїдання канапки або перегляд телебачення. «Сукупність соціальних мереж спричиняє те, що наш інтелектуальний світ зменшується до розміру нашого безпосереднього оточення. А це саме думки, впорядковані в слова - на екрані комп’ютера чи на аркуші паперу, - розширюють горизонт» ${ }^{18}$. Наприклад, 3 огляду на те, що твітерування переважно має форму необгрунтованих поверхневих думок або опису власних прозаїчних дій, Н. Габлер пов'язує з ним появу стану антимислення.

Ідеологія інтернету. Поява homo videns та cвimy nоcmideї засвідчують якісно нові можливості ЗМІ: вони стають самодостатнім суб'єктом медіатизації й спроможні вторгатися в еволюційні процеси людини і світу. Таку тенденцію можемо констатувати й в ідеологічній площині з появою інтернету, специфіка комунікування в якому хоч і позначена ліберальними ознаками, проте дослідники констатують ідеологічно самодостатній характер впливу мережі: «Ідеологія - це не тільки технологія чи засіб інформації, а також й ідеологія. На відміну від усіх інших попередніх технічних інновацій, інтернету властива революційна візія світу й суспільний проект, що, зрештою, спричинилося до його успіху. Без цієї ідеологічної та ідилічної надбудови він не досягнув би такого загального та вражаючого успіху» ${ }^{19}$. За своїм інтеграційним потенціалом ідеологія інтернету є різновидом ідеологій-світоглядів, так званою «глобальною ідеологією». Мережу трактують як open source, open office (усе відкрите i, як наслідок, уможливлює вільний доступ), з нею пов'язують громадянську журналістику, розум натовпу, колективну творчість, сумнів щодо думок експертів й протест проти усього того, що є top-down (усе, що йде від вершини до низів, тобто має авторитарний характер й протиставляється тому, що йде знизу, від спільноти, є антитоталітарним). Автор праці «Культ аматора» ${ }^{20}$ Ендрю Кін згаданому антитоталітаризму протиставляє здатність інтернету демократизувати Великі Медіа, Великий Бізнес, Великий Уряд та Великих Експертів. Таким чином, в інтернеті «з'являється нова динаміка зв'язків, яка розмиває старі відносини й залежності, а ієрархія зникає задля функціонування в мережі, де найістотнішою є кількість встановлених з'єднань» ${ }^{21}$. Саме утвердження такої динаміки дає підстави Бернару Пуле говорити про егалітарну ідеологію мережі, джерелом якої є суміш постлівих поглядів та постмодерного релятивізму, наслідком чого є релятивізм журналістський, що зрівнює аматорську журналістику 3 традиційною» ${ }^{22}$. Однією 3 ключових ідеологем егалітарної ідеології є «мудрість натовпу», який, на думку Джеймса Суровєцького 23 , може вирішувати найскладніші проблеми, що не під силу експертам.

\footnotetext{
${ }^{18}$ Gabler, N. Op. cit.

${ }^{19}$ Poulet, B. (2011). Śmierć gazet I przyszłość informacji, Zarne, Wołowiec, s. 179.

${ }^{20}$ Keen, A.(2007). Kult amatora. Jak Internet niszczy kulture, WaiP, Warszawa, s. 35.

${ }^{21}$ Poulet, B. Op. cit., s. 184.

${ }^{22}$ Poulet, B. Op. cit., s. 192.

${ }^{23}$ Surowiecki, J. (2008). La sagesse des foules, Lattès, Paris.
} 
Прихильники ${ }^{24}$ критичного погляду на егалітаризм інтернету порівнюють його з Платонівською доксою як сукупністю суб’єктивних думок, які кружляють на агорі на засадах пліток й спричиняють помилки в істинності суджень. Водночас вони констатують, що у мережі епістема як достовірне знання має обмежені шанси. Платон наголошував, що правдиве знання повинне бути переказане через учителя, тобто бути елементом ієрархізованої системи навчання. Мережева нівеляція ієрархії є фатальною для процесу здобуття знання, адже «для користувача www немає значення, чи він скористається Вікіпедією, чи авторизованою сторінкою Стендфордського університету. Звичайно, Просвітництво і Нові часи ліквідували феодальну ієрахізованість, яка спиралася на станових нерівностях, але дві ієрархії ніколи не піддавали сумніву: між вчителем та учнем, а також між тими, які пишуть, і тими, хто читає» ${ }^{25}$. На 11 думку, сьогодні кожен може написати книжку, про все дискутувати $і$ дискутувати самовпевнено. «Учений Стівен Гокінг казав щось незвичне про природу комсмології, а в коментарі читаємо: «А хто це такий той Гокінг?». Це помста анонімних людей тим, хто зумів вирватися з натовпу. Першим рефлексом маси є зрівняти. Й Інтернет прекрасно виправдовує ці сподівання як медіа символічного насилля незнаного досі масштабу» ${ }^{26}$.

Фактично ми маємо справу з небезпечним антропологічним явищем, перед яким застерігав автор теорії «офірного цапа» Рене Жирар 27. Він казав, що слід уникати стану, в якому всі стають подібними один на одного і входять у неконтрольовані безпосередні зв’язки. «Спочатку ці контакти можуть видаватися такими, що визволяють і приносять радість, бо знищують суспільні поділи та ієрархії, але невдовзі з'являється криза. Цей фестиваль свободи неодмінно закінчується насиллям, бо де нема норм, форм і прав, з'являється насилля» ${ }^{28}$. В іншому випадку найгірші інстинкти (антиелітарні, реваншистські), які людство впродовж останніх кількох тисяч років намагалося цивілізувати, повернулися в інтернеті з мстивою нав’язливістю. На думку польської дослідниці Агати Бєлік-Робсон, це може спричинити занепад Заходу. Вона стверджує, що західна цивілізація удару під назвою «інтернет» не витримає. Так, як винахід друку їі уможливив, так винахід інтернету і1і знищить. Цивілізація впаде, як Рим, що у період свого занепаду творив людей, які хотіли лише хліба та видовищ.

\section{6. Висновки}

3 моменту свого зародження у XVII столітті й аж до другої половини XX століття 3МI, попри декларовану функцію контролю влади, переважно були посередником між владою і суспільством, тобто їхній вплив на споживача інформації мав вторинний характер, був наслідком впливу влади, політичних сил на медіа. Інакше

${ }^{24}$ Polityka (2018), «Prof. Agata Bielik-Robson o tym, jak internet zabija cywilizację», доступно за адресою: $\quad$ https://www.polityka.pl/tygodnikpolityka/spoleczenstwo/1735694,1,prof-agata-bielikrobson-o-tym-jak-internet-zabija-cywilizacje.read (дата перегляду 25 листопада 2019).

${ }_{25}$ Polityka (2018), «Prof. Agata Bielik-Robson o tym, jak internet zabija cywilizację», доступно за адресою: https://www.polityka.pl/tygodnikpolityka/spoleczenstwo/1735694,1,prof-agata-bielikrobson-o-tym-jak-internet-zabija-cywilizacje.read (дата перегляду 25 листопада 2019).

${ }^{26}$ Ibid.

${ }^{27}$ Girard, R. (1986). The Scapegoat, Johns Hopkins University Press, Baltimore, 216 p.

${ }^{28}$ Polityka (2018), «Prof. Agata Bielik-Robson o tym, jak internet zabija cywilizację», доступно за адресою: $\quad$ https://www.polityka.pl/tygodnikpolityka/spoleczenstwo/1735694,1,prof-agata-bielikrobson-o-tym-jak-internet-zabija-cywilizacje.read (дата перегляду 25 листопада 2019). 
кажучи, преса, радіо стали ретрансляторами владних повідомлень, ідеологем чи міфологем. 3 утвердженням телебачення зміст його впливу на формування системи цінностей глядача залежить не тільки від політичного дискурсу, а й набуває самодостатніх ознак, які не вписуються у пріоритети традиційних ідеологій. Це дає підстави говорити про окрему медіаідеологію та медіаонтологію, що здатні формувати новий тип людини, візії світу якої сильно узалежнені від показуваних образів та істотно локалізовані.

Якісно нові можливості медіатизації виявила поява соціальних мереж як форми комунікування, не надто сприятливої для появи й поширення великих ідей. Однак світ постідеї зберігає здатність творити латентні ідеології, що зорієнтовані на людський консюмеризм та нарцисизм.

Ще одним чітко вираженим ідеологічним вектором у мережі є егалітаризм, що виявляється у спробах деієрархізувати комунікаційний процес, релятивізувати його зміст. У цьому контексті доречно говорити й про спроби релятивізувати журналістику через зрівнювання ваги журналіста/публіциста та аматора-блогера, якому в умовах кібердемократії та плюралізму здається, що він має що сказати своїм читачам чи глядачам. Однак опір таким тенденціям може зародитися там, де його поява, на перший погляд, є проблематичною. Велика диспропорція між обсягами інформації чи поінформованістю та розумінням світу, в якому людина живе, може спричиняти дискомфорт, стан відчуження від реалій. Саме процеси деієрархізації в мережі створюють попит на спільні орієнтири та критерії розуміння процесів, що відбуваються в реальності. Це і є найважливішим призначенням журналістики, яка уже не може обмежитися звичайною подачею фактів й змушена еволюціонувати у бік представлення їхніх значень, контекстів, джерел та наслідків для життя людини.

\section{REFERENCES}

1. Gabler, N. (2011), «The Elusive Big Idea», The New York Times, Aug. 14.

2. Gerbner, G., Gross, L., Morgan, M., \& Signorielli, N. (1986). Living with television: The dynamics of the cultivation process. In J. Bryant \& D. Zillman (Eds.), Perspectives on media effects, Lawrence Erlbaum Associates, NY, pp. 17-40.

3. Girard, R. (1986). The Scapegoat, Johns Hopkins University Press, Baltimore, 216 p.

4. Hjarvard, S. (2008), «The mediatization of society. A theory of the media agents of social and cultural change», Nordicom Review, no. 29(2), pp. 105-134.

5. Jansson, A. (2002), «The Mediatization of Consumption: Towards an Analytical Framework of Image Culture», Journal of Consumer Culture, vol. 2, no. 1, pp. 5-31.

6. Keen, A. (2007). Kult amatora. Jak Internet niszczy kulture, WaiP, Warszawa, $198 \mathrm{~s}$

7. Livingstone, S. (2009), «On the mediation of everything: ICA presidential address 2008», Journal of communication, vol. 59 (1), pp. 1-18.

8. Mazzoleni, G. (2008), «Mediatization of politics». In: Donsbash W (ed) The international encyclopedia of communication, vol VII, Blackwell, Malden, pp. 3047-3051.

9. Molęda-Zdziech, M. (2013). Czas celebrytów. Mediatyzacja życia publicznego, Difin SA, Warszawa, $444 \mathrm{p}$.

10. Olędzki, J. (1998). Komunikowanie wświecie, ASPRA, Warszawa, 291 s.

11. Pisarek, W. (2006). Słownik terminologii medialnej, Universitas, Kraków, 250 s. 
12. Polityka (2018), «Prof. Agata Bielik-Robson o tym, jak internet zabija cywilizację», доступно за адресою: https://www.polityka.pl/tygodnikpolityka/ spoleczenstwo/1735694,1,prof-agata-bielik-robson-o-tym-jak-internet-zabijacywilizacje.read (дата перегляду 25 листопада 2019).

13. Poulet, B. (2011). Śmierć gazet i przyszłość informacji, Zarne, Wołowiec, $270 \mathrm{~s}$.

14. Powerful effects-minimal effects: Elisabeth Noelle-Neumann, «The Effect of Media on Media Effects Research», Journal of Communication, Vol. 33, No. 3, 1983, pp. 157-165.

15. Sartori, G. (2007). Homo videns. Telewizja i postmyślenie, wyd. Uniwersytetu Warszawskiego, Warszawa, $129 \mathrm{~s}$.

16. Surowiecki, J. (2008). La sagesse des foules, Lattès, Paris, 384 p.

17. Trenaman, J., McQuail, D. (1961). Television and the political image, Menthuen, London, $287 \mathrm{p}$.

\title{
ANTHROPOLOGICAL AND IDEOLOGICAL CONSEQUENCES OF MEDIATIZATION
}

\author{
Taras Lylo \\ Ivan Franko National University of Lviv, \\ Generala Chuprynky Str. 49, 79044, Lviv, Ukraine \\ e-mail:taras.lvlo@lnu.edu.ua \\ https://orcid.org/0000-0003-1673-6648
}

The article presents a theory and practice of the influence media exert on ideological and anthropological process. After reviewing existing discussions of mediatization, a historical approach to the mediatization process is suggested. In addition, mediatization is considered as a double-sided process in which the media on the one hand become an integrated part of other institutions like politics. On the other hand, media simultaneously emerge as an independent institution with an ideology of its own that other social institutions have to accommodate to.

The author considers some consequences of mediatization such as homo videns (in the context of Giovanni Sartori's theory, according to which with the appearance of television and the establishment of the television industry in the mid-twentieth century human development was interrupted and reversed, for image perception began to replace abstract thinking), post-idea world that has sprung up alongside the social networking world (Neal Gabler's interpretation).

The article also examines the ideological features of the Internet in particular so-called egalitarian ideology (Bernard Poulet), which gives them the ability talk to each other, and even to contribute their own stories via 'citizen journalism' and blogs.The article also presents a critical view of de-hierarchization of the web that, according to Agata Bielik-Robson, works as a medium of symbolic violence.

Key words: mediatization; ideology; media; homo videns; Internet. 